\title{
PENGARUH RECEIVALBEL TURN OVER DAN DEBT TO ASSET RATIO (DAR) TERHADAP RETURN ON ASSET (ROA) PADA PERUSAHAAN PERTANIAN YANG TERDAFTAR DI BURSA EFEK INDONESIA
}

(BEI)

\author{
M. BASRI KAMAL \\ Dosen Fakultas Ekonomi \\ Universitas Muhammadiyah Sumatera Utara
}

\begin{abstract}
ABSTRAK
Penelitian ini mempunyai tujuan untuk menguji dan mengetahui pengaruh Receivable Turnover dan Debt to Asset Ratio terhadap Return on Asset pada perusahaan Pertanian yang terdaftar di Bursa Efek Indonesia.

Pendekatan yang dilakukan dalam penelitian ini adalah pendekatan kuantitatif dan asosiatif. Populasi dalam penelitian ini adalah seluruh perusahaan Pertanian yang terdaftar di Bursa Efek Indonesia (BEI) dari Periode 2009-2013 yang berjumlah 8 perusahaan. Sedangkan sampel yang memenuhi kriteria dalam penarikan sampel untuk penelitian ini adalah berjumlah 8 perusahaan. Variabel independen dalam penelitian ini terdiri dari Receivable Turnover dan Debt to Asset Ratio, sedangkan variabel dependennya adalah Return on Asset . Teknik pengumpulan data dalam penelitian ini adalah dengan menggunakan teknik dokumentasi. Sementara itu teknik analisis yang digunakan adalah regresi linier berganda, uji asumsi klasik, uji hipotesis (uji t dan uji F) dan koefisien determinasi. Pengolahan data dalam penelitian ini menggunakan program Software SPSS (Statistic Package for the Social Science) 16.00 for windows.

Hasil dari penelitian ini membuktikan bahwa Receivable Turnover dan Debt to Asset Ratio secara parsial berpengaruh tidak signifikan terhadap Profitabilitas (ROA). Sedangkan secara simultan penelitian ini membuktikan bahwa Rceivable Turnover dan Debt to Asset Ratio berpengaruh tidak signifikan terhadap Profitabilitas (ROA) pada perusahaan Pertanian yang terdaftar di Bursa Efek Indonesia periode 2009-2013.
\end{abstract}

Kata Kunci : Return on Asset, Receivable Turnover, Debt to Asset Ratio.

\section{PENDAHULUAN}

Perkembangan dunia usaha dewasa ini yang semakin pesat merupakan dampak dari meningkatnya persaingan usaha yang kompetitif. Menghadapi keadaan ini perusahaan atau pimpinan perusahaan berusaha untuk menciptakan atau meningkatkan nilai perusahaan serta mampu mengolah faktor-faktor produksi yang dimiliki secara efektif dan efisien agar tujuan perusahaan tercapai.

Tujuan perusahaan yang utama adalah mempertahankan kelangsungan hidupya (going concern) serta pencapaian laba yang optimal. Perusahaan dituntut untuk mampu menentukan kinerja usaha yang baik sebagai jaminan kelangsungan hidupnya. Tidak sedikit perusahaan yang menjual produk-produknya secara kredit kepada pelanggan .

Transaksi penjalan secara kredit seperti ini pada umnya disebut piutang, Piutang merupakan bagian penerimaan perusahaan yang sangat penting yang timbul sebagai akibat dari adanya kebijakan penjualan barang atau jasa dengan kredit, dimana debitur 
tidak memberikan suatu jaminan yang secara resmi. Rudianto (2012, hal. 210) menerangkan : Piutang adalah klaim perusahaan atau uang, barang atau jasa kepada pihak lain akibat transaksi dimasa lalu."

Jika dilihat dari prospeknya, industri saat ini sangat menguntungkan. Namun dilihat dari fenomena yang ada, bahwa tidak semua perusahaan industri memiliki prospek yang bagus. Bila kita membicarakan hasil penjualan, maka kita akan membicarakan profit atau keuntungan. Profit atau keuntungan dapat diukur atau dinilai dari kinerja keuangan perusahaan.

Profit atau keuntungan merupakan tujuan utama berdirinya setiap perusahaan. Perusahaan dalam aktivitasnya selalu berusaha untuk mencapai laba yang optimal. Dengan demikian perusahaan dapat mempertahankan kelangsungan hidupnya. Karena itu setiap perusahaan yang berdiri harus mempunyai laporan keuangan agar suatu perusahaan dapat mengetahui kondisi kesehatan keuangan perusahaan tersebut. Setiap perusahaan tentunya menginginkan laba atau profit yang besar dari setiap penjualannya. Hal ini dapat diukur dengan rasio profitabilitas, profitabilitas merupakan salah satu indikator yang digunakan untuk mengukur kinerja keuangan perusahaan.

Menurut Kasmir (2012, hal. 114) rasio profitabilitas merupakan rasio untuk menilai kemampuan perusahaan dalam mencari keuntungan atau laba dalam suatu periode tertentu. Rasio ini juga memberikan ukuran tingkat efektivitas manajemen suatu perusahaan yang ditunjukkan dari laba yang dihasilkan dari penjualan atau dari investasi. Ada beberapa alat ukur yang dipergunakan untuk mengukur tingkat profitabilitas, antara lain : Return On Assets (ROA), dan Return On Equity (ROE). Gross Profit Margin (GPM), Net Profit Margin (NPM), Operating Profit Margin (OPM). Dan didalam penelitian ini profitabilitas akan diukur dengan menggunakan Return On Assets (ROA).

Perusahaan akan melakukan berbagai aktivitas untuk mencapai tujuannya memperoleh profit atau laba demi menjaga keberlangsungan hidup perusahaan, karena profit digunakan untuk dapat melangsungkan kegiatan operasionalnya. Demikian hal nya dengan perusahan pertanian yang terdaftar di Bursa Efek Indonesia (BEI) peroide 2009-2013 dan termasuk dalam kelompok industri manufaktur.

\section{KAJIAN TEORI}

\section{Profitabiliti}

Return On Assets (ROA) merupakan bagian dari rasio profitabilitas dalam menganalisa laporan keuangan atas laporan kinerja keuangan perusahaan. Pengukuran kinerja dengan Return On Assets (ROA) menunjukkan kemampuan dari modal yang diinvestasikan dalam keseluruhan aktiva untuk menghasilkan laba. Rasio ini dipergunakan untuk mengukur kemampuan perusahaan dalam menghasilkan keuntungan dengan penggunaan keseluruhan aktiva perusahaan yang dimiliki. Rasio ini diperoleh dari laba bersih setelah pajak dibagi total aktiva.

Return On Aseets (ROA) menggambarkan sejauh mana kemampuan aset-aset yang dimiliki perusahaan bisa menghasilkan laba. Berhubungan dengan pengertian Return On Assets (ROA), maka berikut ini beberapa pendapat para ahli yang memiliki pengertian atau defenisi yang berbeda-beda dan saling berbeda pendapat dalam penyampaiannya.

Munawir (2010, hal. 89) Return on Invesment itu sendiri adalah salah satu bentuk dari rasio profitabilitas yang dimaksud dengan dapat mengukur kemampuan perusahaan 
dengan keseluruhan dana yang ditanamkan dalam aktiva yang digunakan untuk operasinya perusahaan untuk menghasilkan keuntungan.

Kasmir (2012, hal. 201) Hasil pengembalian investasi atau lebih dikenal dengan nama Return On Invesment atau Return On Assets merupakan rasio yang menunjukkan hasil (return) atas jumlah aktiva yang digunakan dalam perusahaan, Return On Invesment (ROI) juga merupakan suatu ukuran tentang efektivitas manajemen dalam mengelola investasinya.

Sedangkan menurut Syamsuddin (2009, hal. 63) Return On Invesment (ROI) atau sering disebut dengan Return On Assets (ROA) merupakan pengukuran kemampuan perusahaan secara keseluruhan didalam menghasilkan keuntungan dengan jumlah keseluruhan aktiva yang tersedia dalam perusahaan.

Menurut Brighman dan Houston (2010, hal. 148) Rasio Return On Assets (ROA) dapat diukur dengan rumus sebagai berikut :

Return On Assets = Laba Bersih Setelah Pajak

Total Aktiva

Rasio ini adalah suatu cara yang digunakan untuk melihat keberhasilan seorang manajer dalam menjalankan tugasnya. Dengan rasio ini pendapatan atau laba akan dibandingkan dengan dana yang ditanamkan.

\section{a. $\quad$ Faktor-Faktor Yang Mempengaruhi Return On Assets (ROA)}

Apabila kinerja perusahaan baik dan menghasilkan laba bersih yang tinggi atas penggunaan total asset perusahaan secara optimal maka dapat mempengaruhi nilai dari perusahaan dan kinerja perusahaan untuk menghasilkan laba tersebut dapat dipengaruhi oleh faktor-faktor. ROA mempunyai faktor-faktor yang dipengaruhi. Faktor-faktor tersebut berhubungan dengan penjualan.

Menurut Munawir (2010, hal. 89) ROA dipengaruhi oleh dua faktor, yaitu :

1) Turnover dari operating asset (tingkat perputaran aktiva yang digunakan untuk beroperasi) yaitu merupakan ukuran tentang sampai seberapa jauh aktiva ini yang telah dipergunakan didalam kegiatan perusahaan atau menunjukkan berapa kali operating asset berputar dalam satu periode tertentu, biasanya satu tahun.

2) Profit margin, yaitu besarnya keuntungan operasi yang dinyatakan dalam persentase dan jumlah penjualan. Profit margin ini mengukur tingkat keuntungan yang dapat dicapai oleh perusahaan dihubungkan dengan penjualannya.

Rasio ini merupakan rasio terpenting diantara rasio profitabilitas yang lainnya. Semakin besar Return On Asset (ROA) menunjukkan kinerja yang semakin baik, karena tingkat pengambilan semakin besar. Return On Asset (ROA) menunjukkan kemampuan perusahaan dalam menghasilkan laba dari aktiva yang digunakan.

Selain itu Syamsuddin (2009, hal. 63) menyebutkan faktor-faktor yang mempengaruhi Return On Asset (ROA) yaitu:

Return On Asset (ROA) adalah merupakan pengukuran kemampuan perusahaan secara keseluruhan didalam menghasilkan keuntungan dengan jumlah kseluruhan aktiva yang tersedia didalam perusahaan, yang dipengaruhi oleh TurnOver dari Operating Asset, Profit Margin, penjualan, perputaran total aktiva.

\section{b. Tujuan Dan Manfaat Return On Assets (ROA)}

Return On Asset memiliki tujuan dan mafaat tidak hanya bagi pihak pemilik perusahaan atau manajemen saja, tetapi juga bagi pihak luar perusahaan terutama pihak-pihak yang memiliki hubungan atau kepentingan dengan perusahaan . 
Menurut Kasmir (2012, hal.197-198) tujuan penggunaan Return on Asset bagi perusahaan maupun bagi pihak luar yaitu :

1) Untuk mengukur atau menghitung laba yang diperoleh perusahaan dalam suatu periode tertentu .

2) Untuk menilai posisi laba perusahaaan tahun sebelumnya dengan tahun sekarang.

3) Untuk menilai perkembangan laba dari waktu ke waktu .

4) Untuk menilai besarnya laba bersih sesudah pajak dengan modal sendiri .

5) Untuk mengukur produktivitas dari seluruh dana perusahaan yang digunakan baik modal sendiri. untuk :

Adapun pendapat Kasmir (2012, hal.198) manfaaat yang diperoleh adalah

1) Mengetahui besarnya tingkat laba yang diperoleh perusahaan dalam satu periode

2) Mengetahui posisi laba perusahaan tahun sebelumnya dengan tahun sekarang.

3) Mengetahui perkembangan laba dari waktu ke waktu

4) Mengetahui besarnya laba bersih sesudah pajak dengan pajak sendiri.

5) Mengetahui produktivitas seluruh dana perusahaan yang digunakan baik modal sendiri maupun pinjaman.

c. Pengukuran Return On Assets (ROA)

Return On Asset (ROA) menunjukkan kemampuan perusahaan dalam menghasilkan laba dari aktiva yang digunakan. Return On Asset (ROA) merupakan rasio yang terpenting di antara rasio profitabilitas yang ada. ROA diperoleh dengan cara membandingkan laba bersih setelah pajak terhadap total aktiva. Secara keseluruhan didalam menghasilkan keuntungan dengan jumlah keseluruhan aktiva yang tersedia didalam perusahaan.

Menurut Sartono (2012, hal. 123) Return On Asset (ROA) dapat diukur dengan rumus :

$$
R O A=\frac{\text { Laba setelah pajak }}{\text { Total Aktiva }}
$$

Sedangkan Harmono (2009, hal. 110) Return On Asset (ROA) dapat diukur dengan nama :

$$
R O A=\frac{\text { Laba bersih setelah pajak }}{\text { Total Aktiva }}
$$

\section{Perputaran Piutang}

Piutang merupakan pos penting dalam perusahaan karena merupakan bagian aktiva lancar yang likuiditas dan selalu dalam keadaan berputar. Artinya, piutang dapat dijadikan menjadi kas dengan segera dimana jangka waktu paling lama satu tahun. Piutang yang dimiliki satu perusahaan mempunyai hubungan yang erat dengan volume penjualan kredit.

Piutang merupakan bagian penerimaan perusahaan yang sangat penting yang timbul sebagai akibat dari adanya kebijakan penjualan barang atau jasa dengan kredit, dimana debitur tidak memberikan suatu jaminan yang secara resmi. Rudianto (2012, hal. 210) menerangkan : Piutang adalah klaim perusahaan atau uang, barang atau jasa kepada pihak lain akibat transaksi dimasa lalu."

Menurut Kasmir (2012, hal. 176) perputaran piutang merupakan rasio yang digunakan untuk mengukur berapa lama penagihan piutang selama satu periode atau berapa kali dana yang ditanam dalam piutang ini berputar dalam satu periode. 
Menurut Syamsuddin (2009, hal. 49) perputaran piutang adalah untuk mengukur likuiditas atau aktivitas dari piutang perusahaan.

\section{a.Faktor- faktor yang Mempengaruhi Besar Kecilnya Piutang}

Perputaran piutang yang dimiliki suatu perusahaan mempunyai hubungan yang erat dengan jumlah penjualan kredit, sehingga didalam usaha pengendalian piutang dilakukan oleh perusahaan adalah melalui kebijakan kredit yaitu harus memperhatikan tentang besarnya kebijakan penjualan kredit yang dilakukan oleh perusahaan terhadap hasil produksinya. Terdapat beberapa faktor penting piutang menurut Syamsuddin ( 2009, hal. 256 ) antara lain :

1) Kebijaksanaan Kredit

Kebijaksanaa penjualan kredit adalah merupakan pedoman yang ditempuh oleh perusahaan dalam menentukan apakah kepada seseorang langgan akan diberikan kredit dan kalau diberikan berapa banyak atau berapa jumlah kredit yang akan diberikan tersebut.

2) Persyaratan Kredit

Persyaratan kredit atau Credit Term menunjuk kepada pembayaran yang disyaratkan kepada para langganan yang membeli secara kredit, misalnya hal tersebut mungkin dinyatakan sebagai berikut : $2 / 10$ net 30 . Persyaratan kredit seperti ini mengandung arti bahwa pembeli akan menerima potongan tunai atau cash discount sebesar $2 \%$ apabila pembayaran kredit dilakukan paling lama sepuluh hari setelah awal periode kredit. Bila mana pembeli tidak mengambil potongan tunai yang ditawarkan ( tidak membayar dalam waktu 10 hari ) maka keseluruhan jumlah utangnya ( piutang bagi perusahaan penjual ) harus dibayar dalam waktu paling lambat 30 hari sesudah awal periode kredit. Dengan demikian, persyaratan kredit atau Credit Tern meliputi tiga hal yaitu, :

a. Potongan tunai atau cash discount

b. Periode potongan tunai ( dalam contoh diatas 10 hari )

c. Periode kredit ( dalam contoh diatas 30 hari ).

Perubahan dari ketiga ataupun salah satu faktor - faktor diatas akan membawa pengaruh terhadap profitabilitas perusahaan.

3) Kebijaksanaan Pengumpulan Piutang

Kebijaksanakan pengumpulan piutang suatu perusahaan adalah merupakan prosedur yang harus diikuti dalam mengumpulkan piutang -piutangnya bila mana sudah jatuh tempo. Sebagaimana dari keefektifan peusahaan dalam menerapkan kebijaksanaan pengumpulan piutangnya dapat dilihat dari jumlah kerugian piutang atau bad debt expenses, karena jumlah piutang yang dianggap sebagai kerugian tersebut tidak hanya tergantung pada kebijaksanaan pengumpulan piutang tetapi juga kepada kebijaksanakebijaksanaan penjualan kredit yang diterapkan.

\section{b. Pengukuran Perputaran Piutang}

Perputaran piutang menunjukkan seberapa cepat piutang yang dapat dikonversikan ke kas. Perputaran piutang dianalisis untuk menilai keefektifan piutang yang dapat ditoleransi. Semangkin baik (cepat) tingkat perputaran piutang perusahaan maka semangkin efektif pengelolaan piutangnya dan semangkin cepat piutang dapat dikonversikan ke kas sehingga profitabilitas meningkat.

Menurut Sartono (2012, hal. 119) :

bahwa perputaran piutang (receivable turn over) dapat dihitung dengan cara membagi penjualan kredit dengan piutang.

$$
\text { Perputaran Piutang }=\frac{\text { Penjualan Kredit }}{\text { Piutang }}
$$


Menurut Kasmir ( 2010, hal. 176) :

pengukuran tingkat perputaran piutang adalah sebagai berikut:

$$
\text { Perputaran Piutang }=\frac{\text { Penjualan Kredit }}{\text { Rata }- \text { rata Piutang }}
$$

\section{Debt to Asset Ratio}

\section{a. Pengertian Debt to Asset Ratio}

Keputusan modal perusahaan berkaitan erat dengan sumber dana, baik yang berdari aspek internal maupun aspek eksternal perusahaan .Modal adalah hak dan bagian yang dimiliki oleh perusahaan yang ditujukan dalam modal (modal saham), surplus dan laba yang ditahan, atau kelebuhan nilai aktiva yang dimiliki perusahaan terhadap seluruh utangnya, artinya modal merupakan suatu dana perusahaan dalam menjalankan usahanya baik yang berasal dari perusahaan juga pinjaman dari luar perusahaan.

Struktur modal merupakan masalah penting dalam hal pengambilan keputusan mengenai pembelanjaan perusahaan, struktur modal tersebut tercermin pada hutang jangka panjang dan unsure-unsur modal sendiri. Struktur modal dapat mengindifikasikan sejauh mana manajemen mampu mengolah struktur dengan optimal dan mempertimbangkan rata-rata biaya modal yang efisien.

Menurut Sartono (2012, hal 225) menyatakan bahwa "Struktur modal merupakan perimbangan jumlah utang jangka pendek yang bersifat permanen, utang jangka panjang,saham preferen dan saham biasa". Suatu perusahaan melakukan aktivitas bisnis dengan mengandalkan dari modal sendiri tetapi memiliki resiko bisnis yang mungkin timbul dari aktivitas operasionalnnya, akan tetapi apabila tidak mengendalikan dana dari modal pinjaman, akibatnya dari adanya utang maka akan timbul kewajiban kepada pihak luar untuk melunasi pembayaran pada waktu yang telah ditetapkan.

Sedangkan menurut Riyanto (2009, hal 22) Struktur modal adalah pembelanjaan permanen dimana perimbanagan antara utang jangka panjang denan modal sendiri.

Jadi dari pendapat di atas dapat disimpulkan bahwa Struktur modal adalah penggunaan modal pinjaman yang bertujuan untuk memaksimalkan kekayaan pemilik. Dimana struktur modal merupakan keputusan keuangan yang kompleksda seorang manajer keuangan harus dapat menilai struktur modal perusahaan dan memahami hubunga nya dengan resiko.

Rasio struktur modal yang menjadi fokus penelitian ini adalah Debt to On Asset Ratio merupakan salah satu rasio leverage yang bertujuan untuk mengukur kemampuan dari total aktiva yang dijadikan jaminan untuk keseluruhan utang perusahaan.

\section{b. Manfaat Struktur Modal ( Debt to Asset Ratio)}

Struktur modal juga mempunyai manfaat besar suatu pembiayaan dengan pinjaman yaitu melalui pengurangan pajak yang diperoleh dari pemerintahan yang mengizinkan bahwa bunga atas pinjaman dapat mengurangi dalam menghitung pendapatan kena pajak

Manfaat Debt to Asset Ratio menurut Kasmir (2012, hal.154) adalah :

1) Untuk menganalisis posisi perusahaan terhadap kewajiban kepada pihak lainnya( kreditor) 
2) Untuk menganalisis kemampuan perusahaan dalam memenuhi kewajiban yang bersifat tetap .

3) Untuk menganalisis keseimbangan antar nilai aktiva khususnya aktiva tetap dan modal .

4) Untuk menganalisis keseibangan antar nilai aktiva khsusnya aktiva tetap dan modal.

Intinya manfaat Debt to Asset Ratio yaitu mengetahui beberapa hal berkaitan dengan halmodal sendiri dan modal pinjaman serta mengetahui rasio kemampuan perusahaan untuk memenui kewajibannya.

\section{Faktor-faktor yang mempengaruhi Debt to Asset Ratio}

Dalam menentukan struktur modal yang optimal ,perusahaan akan mempertimbangkan faktor-faktor yang mempengaruhi penentuan struktur modal tersebut. Menurut Brigham dan Houston (2011, hal.188-190) mengatakan bahwa struktur modal dipengaruhi oleh beberapa faktor yaitu :
1) Stabilitas penjualan
2) Struktur asset
3) Leverage operasi
4) Tingkat pertumbuhan
5) Profitabilitas
6) Pajak
7) Kendali
8) Sikap manajemen
9) Sikap pemberi pinjaman
10) Kondisi luar
11) Kondisi internal perusahaan
12) Fleksibilitas keuangan

\section{d. Pengukuran Debt to Asset Ratio}

Rasio ini merupakan perbandingan antara utang lancar dan utang jangka panjang dan jumlah seluruh aktiva yang diketahui. Rasio ini menunjukkan beberapa bagian dari keseluruhan aktiva yang dibelanjai oleh hutang.

Pengukuran Debt to Asset Ratio Rasio ini merupakan perbandingan antara utang lancar dan utang jangka panjang dan jumlah seluruh aktiva ang diketahui. Rasio ini menunjukkan beberapa bagian dari keseluruhan aktiva yang dibelanjai oleh hutang.

Rasio ini dapat dihitung dengan rumus, menurut Harmono (2009, hal.112) yaitu:

Debt to Asset Ratio $=\frac{\text { Total Hutang }}{\text { Total Aktiva }}$

Dan rumus Debt to Asset Ratio menurut Sartono (2012, hal. 121) yaitu:

Debt to Asset Ratio $=\frac{\text { Total Hutang }}{\text { Total Aktiva }}$ 
Dari rumus di atas dapat dimbil kesimpulan bahwa Debt to Asset Ratio merupakan mengukur bagian aktiva yang dibagian aktiva yang digunakan untuk menjamin keseluruhan kewajiban atau utang .

\section{B . Kerangka Konseptual}

\section{Pengaruh Receivable Turnover Terhadap Return on Asset}

Piutang muncul karena perusahaan melakukan penjulan secara kredit untuk meningkatkan volume usahanya. Setiap perusahaan, apakah perusahaan itu perusahaan dagang ataupun perusahaan pabrik selalu mengadakan perputaran piutang. Tingkat perputaran piutang mempengaruhi rentabilitas perusahaan karena dengan adanya peningkatan perputaran piutang maka volume penjualan juga akan meningkat sehingga laba yang diterima perusahaan akan bertambah .

Menurut Kasmir (2012, hal. 176) "Semangkin tinggi rasio perputaran piutang menunjukkan bahwa modal kerja yang ditanamakan dalam piutang semangkin rendah (bandingkan dengan rasio tahun sebelumnya) dan tentunya kondisi ini bagi perusahaan semangkin baik. Sebaliknya jika rasio semangkin rendah ada over invesment dalam piutang".

Tingkat perputaran piutang mempengaruhi rentabilitas perusahaan karena dengan adanya peningkatan perputaran piutang maka volume penjualan juga akan meningkat sehingga laba yang diterima perusahaan akan bertambah. Adapun hasil penelitian terdahulu Dwi Putri, Deffi (2014) yang menyatakan bahwa tingkat perputaran piutang berpengaruh positif terhadap profitabilitas. Dari uraian diatas maka diduga perputaran piutang berpengaruh terhadap profitabilitas.

\section{Pengaruh Debt to Asset Ratio terhadap Return on Asset}

Untuk menjalankan operasinya setiap perusahaan memiliki berbagai kebutuhan, tertama yang berkaitan dengan dana agar perusahaan dapat berjalan dengan semestinya. Dana selalu dibutuhkan untuk menutupi seluruh atau sebagian dari biaya yang diprlukan, baik dana jangka pendek maupun dana jangka panjang. Dana juga dibutuhkan untuk melakukan ekspansi atau perluasan usaha atau investasi baru. Artinya,didalam perusahaan harus selalu tersedia dana dalam jumlah tertentu sehingga tersedia pada saat dibutuhkan. Dalam hal ini, tugas manajer keunganlah yang bertugas memenuhi ebuthan tersebut.

Perusahaan-perusahaan lebih memilih pembiayaan internal daripada menggunakan pinjaman untuk mendanai investasi barunya maupun untuk tambahan modal . Perusahaan-perusahaan dengan profitabilitas yang tinggi akan menggunakan lebih banyak laba ditahan dan lebih sedikit utang. Oleh karena itu besarnya komponen utang akan berhubungan dengan tingkat Profitabilitas.

Menurut Kasmir (2012, hal. 156) Debt to Asset Ratio yaitu:

"Rasio utang yang digunakan untuk mengukur perbandingan antara total utang dengan total aktiva. Dengan kata lain, seberapa besar aktiva perusahaan diiayai oleh utang atau seberapa besar utang perusahaan berpengaruh terhadap pengolahaan aktiva.

Dari hasil pengukuran, apabila rasionya tinggi, artinya pendanaan dengan utang semakin bnyak, maka semakin sulit bagi perusahaan untuk memperoleh tambahan 
pinjaman karena dikhawatirkan perusahaan tidak mampu menutupi utang-utangnya dengan aktiva yang dimilikinya.

Adapun hasil penelitian terdahulu Dewa Kadek Oka Kusumajaya (2011) menyatakan bahwa tingkat perputaran Debt to Asset Ratio berpengaruh positif terhadap Return on Asset. Jika perusahaan memutuskan menetapkan struktur modal dalam jumlah yang besar, kemungkinan tingkat likuiditas akan terjaga namun kesempatan untuk memperoleh laba yang besar akan menurun yang pada akhirnya berdampak pada menurunnya profitabilitas.

\section{Pengaruh Receivable Turn Over dan Debt to Asset Ratio terhadap Return on Asset}

Semangkin tinggi Return On Assets maka akan semangkin baik perusahaan tersebut dalam menggunakan aktiva dan kegiatan operasionalnya dan sebaliknya jika Return On Assets rendah maka perusahaan belum mampu dalam hal mengelola aktiva yang dimiliki dalam kegiatan operasionalnya.

Menurut Kasmir (2012, hal. 176) "Semangkin tinggi rasio perputaran piutang menunjukkan bahwa modal kerja yang ditanamakan dalam piutang semangkin rendah (bandingkan dengan rasio tahun sebelumnya) dan tentunya kondisi ini bagi perusahaan semangkin baik. Sebaliknya jika rasio semangkin rendah ada over invesment dalam piutang".

Hubungan perputaran Debt to Asset Ratio dengan Return on Asset adalah jika perusahaan memutuskan menetapkan struktur modal dalam jumlah yang besar, kemungkinan tingkat likuiditas akan terjaga namun kesempatan untuk memperoleh laba yang besar akan menurun yang pada akhirnya berdampak pada menurunnya profitabilitas. Adapun hasil penelitian terdahulu Sri Dewi Anggadini dan Imam Rajiman (2009) menyatakan bahwa Receivable Turn over dan Debt to Asset Ratio berpengaruh positif terhadap Return on Asset.

Perputaran piutang merupakan bagian dari modal kerja yang dimiliki perananan penting dalam kegiatan operasional perusahaan dan selalu berputar setiap tahunnya. Dimana perputaran piutang menunjukkan kecepatan perputaran piutang dapat kembali menjadi kas .Dengan demikian Tinggi perputaran piutang maka menunjukkan tingginya volume penjualan yang dicapai perusahaan dengan begitu perusahaan akan memperoleh laba. Hubungan Receivable Turn Over dan Debt to Asset Ratio terhadap Return on Asset dapat dilihat pada kerangka konseptual sebagai berikut :

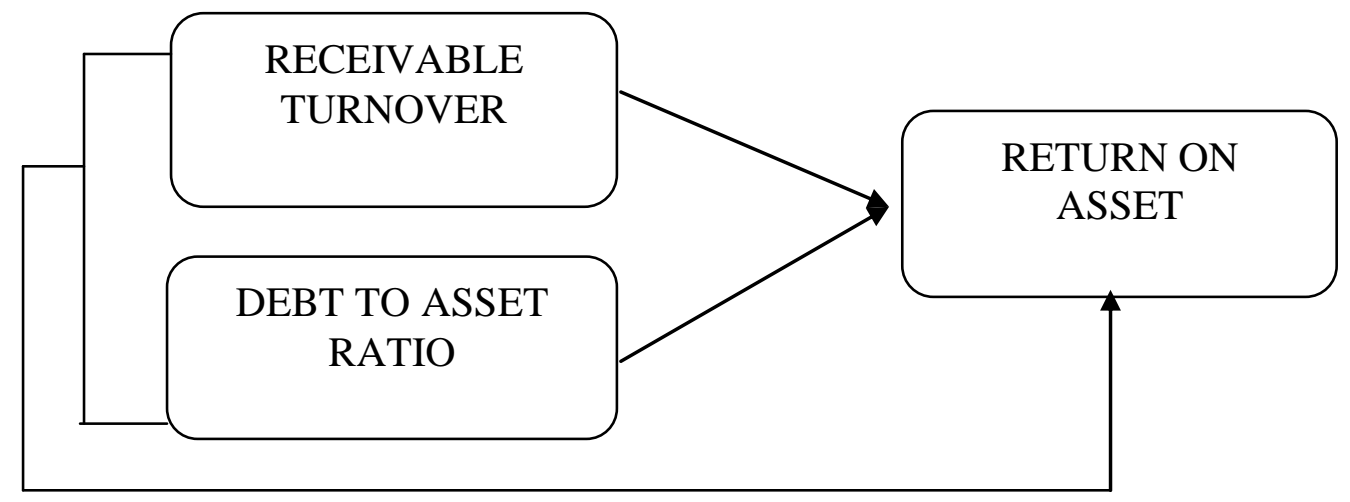

Gambar II-1 : Gambar Paradigma Penelitian 


\section{C . Hipotesis}

Hipotesis adalah jawaban sementara terhadap rumusan masalah diatas (Sugiyono, 2012, hal. 93). Oleh karena itu, jawaban yang diberikan baru berdasarkan pada teori yang relevan, belum didasarkan pada fakta-fakta empiris yang diperoleh melalui pengumpulan data. Hipotesis tersebut bisa tentang prilaku, fenomena, atau keadaan tertentu yang telah terjadi atau yang akan terjadi.

Berdasarkan rumusan setra tujuan dari penelitian ini, maka dapat diaambil hipotesis-hipotesis sebagai berikut :

1. Ada pengaruh Receivable TurnOver terhadap Return On Asset pada Perusahaan Pertanian yang terdaftar di Bursa Efek Indonesia pada Periode 2009- 2013.

2. Ada pengaruh Debt to Asset Ratio terhadap Return On Asset pada Perusahaan Pertanian yang terdaftar di Bursa Efek Indonesia pada Periode 2009- 2013.

3. Ada pengaruh Receivable TurnOver dan Debt to Asset Ratio terhadap Return On Asset pada Perusahaan Pertanian yang terdaftar di Bursa Efek Indonesia pada Periode 2009- 2013.

\section{METODE PENELITIAN}

Pendekatan penelitian yang digunakan peneliti ini adalah dengan menggunakan pendekatan asosiatif. Pendekatan asosiatif adalah pendekatan dengan menggunakan dua atau lebih variabel guna mengetahui hubungan atau pengaruh antar variabel yang satu dengan yang lainnya. Jenis data yang digunakan bersifat kuantitatif yaitu berbentuk angka dengan menggunakan instrumen formal, standart, dan bersifat mengukur metode dan teori yang ada maka penelitian ini berbentuk penelitian.

Teknik pengumpulan data yang digunakan dalam penelitian ini adalah dengan menggunakan teknik dokumentasi. Data yang digunakan dalam penelitian ini dikumpulkan dengan mendekomentasikan dari laporan keuangan perusahaan otomotif yang bersumber dari Bursa Efek Indonesia (BEI). Sumber data yang digunakan dalam penelitian ini adalah sumber data sekunder yang diperoleh dengan mengambil data-data yang di publikasikan oleh Bursa Efek Indonesia (BEI).

Penelitian dilakukan pada perusahaan pertanian yang terdaftar di Bursa Efek Indonesia (BEI) periode 2009 sampai dengan 2013. Waktu penelitian dilaksanakan mulai bulan November 2014 sampai dengan bulan Maret 2015.

Populasi yang digunakan dalam penelitian ini adalah populasi perusahaan pertanian yang menerbitkan laporan keuangan lengkap setelah diaudit di Bursa Efek Indonesia selama periode 2009 sampai dengan 2013 yang berjumlah 8 perusahaan.

Metode yang digunakan dalam penarikan sampel adalah puposive sampling yaitu teknik mengetahui seberapa besar pengaruh Receivabel Turn Over, Debt to Asset Ratio (DAR) terhadap Return on Asset perusahaan. Jenis metode ini termaksud dalam metode penarikan sampel non probability sampling, yaitu metode pengambilan sampel yang tidak memberi peluang atau kesempatan sama bagi setiap unsur atau anggota populasi untuk dipilih menjadi sampel. Hanya elemen populasi yang memenuhi kreteria tertentu dari penelitian ini saja yang bisa menjadikan sampel penelitian. 
Metode analisis yang digunakan dalam analisis ini adalah dengan menggunakan regresi linier berganda, pengujian hipotesis, dan koefisien determinasi .

\section{A. Pembahasan}

Analisis hasil temuan penelitian ini adalah mengenai hasil temuan dan keseuaian teori, pendapat, maupun penelitian terdahulu yang telah dikemukakan sebelumnya serta pola perilaku yang harus dilakukan untuk mengatasi hal tersebut. Berikut ini ada 2 (dua) bagian utama yang akan dibahas dalam analisis hasil temuan penelitian ini, yaitu sebagai berikut :

\section{Pengaruh Receivable Turnover terhadap Return on Asset}

Berdasarkan hasil penelitian diatas, antara Receivable Turnover terhadap Return on Asset pada perusahaan pertanian yang terdaftar di Bursa Efek Indonesia menyatakan bahwa $-\mathrm{t}_{\text {tabel }} \leq \mathrm{t}_{\text {hitung }} \leq \mathrm{t}_{\text {tabel }}$ dengan nilai yakni $\quad-2.024 \leq 0.342 \leq$ 2.024. Hal ini menunjukan bahwa $t_{\text {hitung }}$ berada pada daerah penerimaan $\mathrm{H}_{0}$ atau dengan kata lain $\mathrm{H}_{a}$ ditolak. Jadi kesimpulannya berpengaruh tidak signifikan Receivable Turnover terhadap Return on Asset pada perusahaan pertanian yang terdaftar di bursa efek Indonesia periode 2009-2013.

Berpengaruh positif tidak signifikan Receivable Turnover terhadap Return on Asset arinya, Receivable Turnover meningkat bisa disebabkan adanya penjualan yang menurun dan tidak efektifnya penagihan piutang yang tak tertagih atau adanya penurunan pinjaman, sehingga laba bersih ikut naik, lebih jelasnya dapat dilihat dari tabel IV.5 . Di sebabkan biaya yang tertanam yang belum efisien sehingga Receivable Turnover tidak optimal kembali ke dalam perusahaan, dana yang di peroleh belum dapat di gunakan untuk pembiayaan aktiva lancar perusahaan, ini akan menunjukkan kondisi Return Asset perusahaan yang belum baik. Adapun yang harus di perhatikan oleh perusahan yaitu dalam kegiatan operasi perusahaan itu sendiri. Di antaranya pengolahan receivable turn over masih belum teratur dan efisien, menurunnya kualitas barang, belum terpenuhinya keinginan konsumen. Receivable turnover di pengaruhi antara penjualan dengan rata rata kas yang di miliki oleh perusahaan. Hal ini berarti semakin tinggi receivable turn over tidak mempengaruhi tingginya Return on Asset perusahaan. Hasil penelitian ini sejalan dengan hasil penelitian yang di lakukan oleh Nini Agustini (2013) yang menyatakan bahwa Receivable Turnover berpengaruh tidak signifikan terhadap Return on Asset.

Peneltian ini sesuai dengan teori Riyanto (2009, hal. 91) mengemukakan bahwa “

Tinggi rendahnya receivable turnover mempunyai efek yang langsung terhadap besar kecilnya modal yang diinvestasikan dalam piutang. Mangkin tinggi turnovernya, berarti mangkin cepat perputarannya. Yang berarti mangkin pendek waktu terikatnya modal dalam piutang, sehingga untuk mempertahankan net credit sales tertentu, dengan naiknya turnovernya, dibutuhkan jumlah modal yang lebih kecil yang diinvestasikan dalam piutang.

Berdasarkan hasil penelitian yang dilakukan penulis serta teori, pendapat, maupun penelitian terdahulu yang telah dikemukakan diatas mengenai pengaruh Receivable Turnover terhadap Return on Asset perusahaan. Maka penulis dapat menyimpulkan bahwa ada kesesuaian antara hasil penelitian dengan teori, pendapat dan penelitian 
terdahulu yakni ada pengaruh tidak signifikan Receivable Turnover terhadap profitabilitas (Return On Asset) perusahaan.

\section{Pengaruh Debt to Asset Ratio Terhadap Return on Asset}

Berdasarkan hasil penelitian, antara Debt to Asset Ratio terhadap Return on Asset pada perusahaan pertanian yang terdaftar di Bursa Efek Indonesia menyatakan bahwa $-\mathrm{t}_{\text {tabel }} \leq \mathrm{t}_{\text {hitung }} \leq \mathrm{t}_{\text {tabel }}$ dengan nilai yakni $-2.024 \leq-0.497 \leq 2.024$. Hal ini menunjukan bahwa $\mathrm{t}_{\text {hitung }}$ berada pada daerah penerimaan $\mathrm{H}_{0}$. Jadi kesimpulannya berpengaruh tidak signifikan Debt to Asset terhadap Return on Asset pada perusahaan pertanian yang terdaftar di bursa efek Indonesia periode 2009-2013.

Berpengaruh negatif tidak signifikan Debt to Asset Ratio terhadap Return on Asset arinya, Debt to Asset Ratio menurun bisa disebabkan adanya total hutang yang menurun dan tidak efektifnya pengolahanakiva sehingga laba belum maksimal sehingga laba bersih ikut menurun. Lebih jelasnya dapat dilihat dari tabel IV. 8. Adapun yang harus di perhatikan oleh perusahan yaitu dalam kegiatan operasi perusahaan itu sendiri. Dari hasil pengukuran, apabila rasionya tinggi, artinya pendanaan dengan utang semakin bnyak, maka semakin sulit bagi perusahaan untuk memperoleh tambahan pinjaman karena dikhawatirkan perusahaan tidak mampu menutupi utang-utangnya dengan aktiva yang dimilikinya.

Adapun hasil penelitian terdahulu Dewa Kadek Oka Kusumajaya (2011) menyatakan bahwa tingkat perputaran Debt to Asset Ratio berpengaruh positif terhadap Return on Asset. Jika perusahaan memutuskan menetapkan struktur modal dalam jumlah yang besar, kemungkinan tingkat likuiditas akan terjaga namun kesempatan untuk memperoleh laba yang besar akan menurun yang pada akhirnya berdampak pada menurunnya profitabilitas.

Dari hasil pengukuran, apabila rasionya tinggi, artinya pendanaan dengan utang semakin bnyak, maka semakin sulit bagi perusahaan untuk memperoleh tambahan pinjaman karena dikhawatirkan perusahaan tidak mampu menutupi utang-utangnya dengan aktiva yang dimilikinya.

\section{Pengaruh Receivable Turnover dan Debt to Asset ratio Secara Bersama-sama Terhadap Return On Asset}

Berdasarkan Uji F yang menguji secara simultan yaitu apakah ketiga variabel bebas yakni Receivable Turnover dan Debt to Asset Ratio ada pengaruh tidak signifikan terhadap varibel terikat yaitu Retrun On Asset maka diperoleh nilai $F_{\text {hitung }} 0.213 \leq \mathrm{F}_{\text {table }}$ 3.25 kemudian dilihat dengan hasil nilai probabilitas signifikan $0.809>0,05$, maka Ho diterima dan (Ha ditolak), artinya ada pengaruh tidak signifikan secara simultan terhadap Return on Asset pada perusahaan Pertanian yang terdaftar di Bursa Efek Indonesia (BEI).

Berpengaruh positif tidak signifikan Receivable Turnoer dan Debt to Asset Ratio terhadap Return on Asset arinya, Meningkatnya Receivable Turnover dan meningkatnya Debt to Asset Ratio bisa disebabkan adanya penjualan yang menurun dan tidak efektifnya penagihan piutang dan adanya adanya total hutang yang menurun dan tidak efektifnya pengolahan aktiva sehingga laba belum maksimal sehingga meningkatkan Return on Asset dapat ditingkatkan. Lebih jelasnya dapat dilihat dari 
tabel IV. 5 dan 8. Adapun yang harus di perhatikan oleh perusahan yaitu dalam kegiatan operasi perusahaan itu sendiri.

Dari hasil pengukuran, apabila rasionya tinggi, artinya pendanaan dengan utang semakin bnyak, maka semakin sulit bagi perusahaan untuk memperoleh tambahan pinjaman karena dikhawatirkan perusahaan tidak mampu menutupi utang-utangnya dengan aktiva yang dimilikinya.

Adapun hasil penelitian terdahulu Sri Dewi Anggadini dan Imam Rajiman (2009) menyatakan bahwa Receivable Turn over dan Debt to Asset Ratio berpengaruh positif terhadap Return on Asset.

Perputaran piutang merupakan bagian dari modal kerja yang dimiliki perananan penting dalam kegiatan operasional perusahaan dan selalu berputar setiap tahunnya. Dimana perputaran piutang menunjukkan kecepatan perputaran piutang dapat kembali menjadi kas .Dengan demikian Tinggi perputaran piutang maka menunjukkan tingginya volume penjualan yang dicapai perusahaan dengan begitu perusahaan akan memperoleh laba.

\section{KESIMPULAN}

Berdasarkan hasil penelitian dan pembahasan yang telah dikemukakan sebelumnya maka dapat diambil kesimpulan dari penelitian mengenai pengaruh Receivable Turnover dan Debt to Asset Ratio terhadap Return On Asset pada perusahaan Pertanian yang terdaftar di Bursa Efek Indonesia (BEI) periode 2009- 2013 dengan sampel 8 perusahaan adalah sebagai berikut :

1. Ada pengaruh yang tidak signifikan secara parsial antara Receivable Turnover terhadap Return Turnover, dimana diperoleh nilai $-2.024 \leq \quad-0.342 \leq 2.024$. Dan nilai signifikansi sebesar 0.734 (lebih besar dari 0,05). Hal ini menyatakan bahwa $\mathrm{H}_{0}$ diterima (tolak $\mathrm{H}_{\mathrm{a}}$ ) artinya Receivable Turnover berpengaruh tidak signifikan terhadap Return on Asset pada perusahaan Pertanian di BEI.

2. Ada pengaruh yang tidk signifikan secara parsial antara Debt to Asset Ratio terhadap Return on Asset, dimana nilai $-2.024 \leq-0.498 \leq 2.024$. Dan nilai signifikansi sebesar 0,621 (lebih besar dari 0,05). Hal ini menyatakan bahwa $\mathrm{H}_{0}$ diterima artinya Debt to Asset Ratio berpengaruh tidak signifikan terhadap Return on Asset pada perusahaan Pertanian yang terdaftar di BEI.

3. Ada pengaruh tidak signifikan secara simultan antara Receivable Turnover dan Debt to Asset Ratio terhadap Return on Asset, dimana $\mathrm{F}_{\text {hitung }} 0.213 \leq \mathrm{F}_{\text {table }} 3.25$. kemudian dilihat dengan hasil nilai signifikan 0.809 .Ho diterima, artinya Receivable Turnover dan Debt to Asset Ratio secara bersama-sama ada pengaruh tidak signifikan terhadap Return on Asset pada perusahaan Tekstil dan Garmen yang terdaftar di BEI.

\section{Daftar pustaka}

Brigham, Eugece F. And Housto. (2010). “Dasar-dasar Manajemen Keuangan”. ( Edisi II). Jakarta : Salemba Empat.

Harmono,SE,M.Si . (2009). “Manajemen Kuangan” . CetakanPertama, Jakarta : PT.Bumi Aksara . 
Kasmir (2012). “Analisis Laporan Keuangan” . (cetakan ketiga). Jakarta: PT Raja Grafindo Persada .

Munawir (2010). “Analisis Laporan Keuangan”. (Edisi keempat) Cetakan kelima belas . Liberty Yogyakarta

Riyanto, Bambang (2009). "Dasar-dasar Pembelanjaan Perusahaan”. (Edisi Keempat). Cetakan keenam . Yogyakarta : Liberty .

Rudianto (2012). “Pengantar Akuntansi”. Cetakan pertama. Jakarta : PT. Glora Aksara Pratama .

Sartono, Agus (2012). "Manajemen Keuangan Teori dan Aplikasi" (edisi empat). Cetakan keenam . Yogyakarta, BPFE.

Sugiyono (2012). " Metode Penelitian Bisnis". (Cetakan Ke-16). Bandung : Penerbit Alfabeta .

Bursa Efek Indonesia (2014) . http:www.idx.co.id.

\section{JURNAL}

Sri Dewi Anggadini ( 2012 ), Pengaruh Perputaran Piutang Dan Struktur Modal

Terhadap Profitabilitas Pada Perusahaan Pertanian Yang Terdaftar Di Bursa Efek Indonesia (BEI) Medan : Universitas Komputer Indonesia

Deffi Dwi Putri (2008), "Pengaruh Perputaran Piutang terhadap Profitabilitas (Studi

Internet

Kasus pada Laporan Keuangan PT. Al Ijarah Indonesia Finance Periode2007-2012)”.

Bursa Efek Indonesia (2014). http//www.idx.co.id 